2020, Volume 10, International Conference Globalization, Innovation and Development. Trends and Prospects (G.I.D.T.P.), pages: 429-435 | https://doi.org/10.18662/lumproc/gidtp2018/47

\section{Ecotourism in the Danube Delta Biosphere Reserve}

\section{Dragos Mihai PANAGORET ${ }^{1}$, Andreea PANAGORET*2, Florentina-Raluca BILCAN ${ }^{3}$}

1 Valahia University of Târgovişte, Faculty of Sciences and Engineering Alexandria, România, panagoret dragos@yahoo.com

2 Valahia University of Târgovişte, Faculty of Sciences and Engineering Alexandria, România, andreea panagoret@yahoo.com Corresponding author

${ }^{3}$ University professor, University of Valahia, Targoviste, Bucharest, Romania, rectorat@,valahia.ro
Abstract: In the past years, tourism has been facing a constantly extension. The average annual growth rates has varied from 5 to $10 \%$, making tourism one of the leading sector wich assure worldwide economic and development opportunities This ascending trend was also reflected on ecotourism and has been determined by the expanding desire of city people to go out in nature. These growing trends show us an expanding interest for ecotourism and a transformation of it, starting from a niche market and becoming a leading segment. Although, at the beginning, ecotourism has targeted tourists with experience and with a high level of education and income, now the target tourists have a very wide range of income, education, or travel experiences. The Danube Delta and, implicitly, Danube Delta Biosphere Reserve, represents one of the most significant tourist regions in Romania. Danube Delta is declared a UNESCO's natural heritage and it is considered by many people one of the most attractive tourist destinations of Europe, one of those places that must be visited at least once in a lifetime. The Status of the Danube Delta as protected area has led to a process of reorganization of tourism taking place on this area in the context of using sustainable natural resources and specially the landscape assets with minimal impact on the integrity of natural ecosystems.

Keywords: Ecotourism; Danube Delta; Biosphere Reserve.

How to cite: Panagoret, D.M., Panagoret, A., \& Bilcan, F.R. (2020). Ecotourism in the Danube Delta Biosphere Reserve. In I. Panagoreț \& G. Gorghiu (vol. ed.), Lumen Proceedings: Vol. 10. International Conference Globalization, Innovation and Development. Trends and Prospects (G.I.D.T.P.) (pp. 429-435). Iasi, Romania: LUMEN Publishing House.

https://doi.org/10.18662/lumproc/gidtp2018/47 


\section{Introduction}

Romania is a country with an unique natural and cultural heritage that can attract numerous tourist from all over the world, given that the current tourism trends worldwide indicates an increase of tourists to destinations with natural potential tourism.

The semi-natural and natural ecosystems account for about $47 \%$ of the Romania's surface [1]. Alongside the natural setting, the country benefits from an ethnographic and folkloric potential of great originality and authenticity.

Considered one of the most beautiful destination for ecotourism, the Danube Delta Biosphere Reserve has a threefold conservation status: Biosphere Reserve designated internationally by the UNESCO MAB Committee, Wetland of International Importance designated by the Secretariat of the Ramsar Convention and the Natural Site of Universal Natural Patrimony recognized by UNESCO.

Also The Danube Delta Biosphere Reservation has been awarded by the Council of Europe with the European Diploma.

\section{Theoretical Background}

At the present no definition is unanimously accepted for ecotourism, although several definitions are agreed and mostly accepted [3].

Ecotourism is a type of tourism where the main popose of the tourist is to observe, to appreciate the nature and the local traditions that are related to the nature and which need to meet the following criteria:

1. The use of local workforce;

2. Conservation and protection of nature;

3. Respect for nature, educational character;

4. Minimal negative impact over environment.

All tourism forms must be environmentally, socially and culturally sustainable. Ecotourism differs from the other forms of tourism in that it is dependent on the protection of natural ecosystems.

The challenge for the eco-tourism industry is that of developing the tourist capacity and the quality of the products offered without, however, affecting the natural environment on which it depends. This implies that the type, location and level of tourism practiced do not harm the environment and also that management is adequate to support the appropriate type of ecotourism. 
The expansion of ecotourism activities in local and protected areas implies also socio-economic benefits, mostly [2]:

- generating local employment (directly in the tourism sector or related sectors )

- stimulates local economy through by developing of tourism services and the infrastructure;

- stimulates the rural economy throughout the creation and the increasing request for agricultural products used to provide services for tourists;

- boosting the development of infrastructure, of which the local population can benefit;

- stimulate the development of peripheral regions through capital injections;

- stimulate the improvement of intercultural relations in a region. Often tourists seek to discover traditions and customs specific for an ethnographic region, and the local community is determined to restore old traditions;

- In normal conditions of development, tourism is able to self-finance the development mechanisms that the administrators of protected areas could benefit from as a conservation tool.;

- Sustains the conservation activities through convincing government agencies and the population about how important natural areas are.

The results of many studies show that the Danube Delta has a strong potential for a sustainable human-nature relationship especially in terms of tourism [5].

Nevertheless, tourism could have negative impacts that must not be neglected. The fragility of tourism in the delta is reported in the study of prof. Vaideanu (2015), who highlighted the fact that tourists are demanding more oversights, but the absence of coordination of all actors (government, management and local) and the lack of an integrated management are the cause of an improper functioning of the entire system [7].

\section{Argument of the paper}

The Danube Delta area has significant potential for developing sustainable tourism based on nature and culture. Tourism in this area has remained underdeveloped, which offers opportunities for growth. Taking into account the sensitivity of natural and cultural resources - the principal tourism capital - the development of tourism must be established on meticulous planning and understanding of the gains and losses associated with tourism activities. 
An important opportunity consists in the fact that the type of tourism that suits the characteristics of the territory corresponds to the one that is developing and will make future progress.

Tourism established on the exploration of local culture and knowledge of nature is associated with prolonged periods of stay, a significant increase in spending and an increase of responsible behaviour in relation with biodiversity and the local communities.

According to a recent study by the European Commission and the Council of Europe on the impact of cultural tourism on SMEs, it has significant potential for stimulating innovation and improving the competitiveness of local businesses and entrepreneurs in the area [8].

The main values of the Danube Delta are the nature and the culture, tourist resources of the Reserve, resources that can be redeemed especially by practicing ecotourism [1].

\section{Arguments to support the thesis}

The most known medicinal herb species, but also the largest reefcovered areas in the world and two one of a kind forests in Europe, represented by secular oaks and Mediterranean lianas (Letea and Caraorman forests) can be found in the Danube Delta Biosphere Reserve. The greatest fauna wealth of the reserve is still the birds that land on this territory during migration or who have chosen the delta as a place for feeding, nesting and raising the chickens. All these unique features make the Danube Delta a research and observation lab for researchers from all over the world, but also for nature lovers who visit the delta in search of natural areas and special species [5].

The values of the Reserve are also tourist attractions that can transform into a tourist product and can be organized as:

1. Natural tourism assets:

- The landscape

- Delta Biodiversity

2. Anthropic tourism assets:

- Culture and history of the Danube Delta

- Rural human settlements

These natural values of the delta that create and represent the tourism potential of Danube Delta Biosphere Reserve allow the practice of a variety of forms of tourism:

- stay for rest, practiced through large travel companies, in one of the hotels on the territory of the reservation or using their floating hotels; 
- Itinerant, practiced either individually or through organized tours, of variable duration;

- for practicing water sports;

- for practicing sports fishing and sports hunting;

- specialized tourism for ornithologists, botanists, ihtiologists, etc .;

- programs made special for youth people so that can know, understand and appreciate the nature;

- rural tourism where tourists can be hosted (accommodation, meals) and guided by locals;

- helio-marine cure that can be made on the of the Reserve;

- photo safaris mastered by those who like to capture the wonderful images they have made in the reservation on the film.

Studies reveal that high tourism activity pushes local people to renovate their houses in a modern style with building materials that last longer in time than reed, which makes it difficult to preserve the traditional architecture. Popa, Nichersu, and Poruncia's study (2005) reveals that locals adjust to the socio-economic changes but it is difficult for them, especially after many decades of a centralized system, changes to modern resource use, and building patterns that occurred (not necessarily with their approval) [4]. These conclusions suggest that there is perhaps an inconsistency between the sustainability objectives of the biosphere reserve designation, which include the involvement of the local communities and preservation of their cultural values, and the actual state of development in the Danube Delta[6].

Given the development of tourism and tourism infrastructure that took place in this area, the Danube Delta Biosphere Reserve is an ongoing priority at national, regional and local levels. The main priority is the development of sustainable tourism without affecting natural ecosystems. [9]

One of the most important tourist areas in Romania, the Danube Delta, is a true paradox: though it is unique, it is not visited by too many tourists and the investments are quite difficult.

In the Danube Delta, according to the National Institute of Statistics, there are 7,240 accommodation places.

Statistics from the National Institute of Statistics (INS) show that 58,297 tourists registered in accommodation establishments visited Tulcea County in the first half of 2018 compared to 33,093 in the same period of 2017.

The National Institute for Research and Development claims in a study in which the touristic phenomenon in Danube Delta Biosphere Reserve is investigated, that refining tourism activity implies the reconstruction of all tourism means and also the promotion of the Danube Delta Biosphere Reserve product on the market. These means the 
restructure of touristic forms and resources and also the promotion on the touristic market of the „The Danube Delta Biosphere Reservation”. Everything leads to the development of strictly based eco tourism that involves the following:

- Tourism has to turn, step by step, into a very well organized activity, that is practiced in group or by individuals in collaboration with the administration authorities of the Danube Delta Biosphere Reserve.

- A coherent legislation must be elaborated and applied for tourism inside the reservation.

- The protection and the preserving of Delta ecosystems must lead to the fact that touristic activities which take place within the reservation must be performed only by companies that possess suitable skills.

\section{Conclusions}

The Danube Delta represents an important tourist regions of Romania, due to the resourcefulness landscape with strong points for ecotourism:

- various and plentiful of natural tourism resources;

- bountiful fauna and flora, with one of a kind species in Europe;

- wild areas, untouched by human interference;

- underdeveloped access infrastructure into the protected areas, which limits a major tourist development;

- the legal framework which assures the delimitation of natural parks and protected areas, protected natural habitat regime, natural environmental preservation. skirting it

Danube Delta has a huge touristic potential, but tourists have

All those who have tried to develop and promote Delta need a strategy supported by the Romanian state in order to attract Romanian and foreign tourists in a wonderful but atypical area so it is hard to manage and harder to suit the needs and desires of those who are looking for easy destinations.

\section{References}

[1] Fundația Centrul Național pentru Dezvoltare Durabilă. Natura 2000 în România, Bucureşti; 2012: 6.

[2] Gâştescu P. Delta Dunării - rezervație a biosferei. Bucureşti: Editura CD Press; 2008. 
[3] Manea G. Zone şi arii protejate şi valorificarea lor în turism. Bucureşti: Editura CREDIS; 2005.

[4] Nistoreanu P. Ecoturism si turism rural, Editia a III-a. Bucuresti: Editura ASE; 2006.

[5]Popa LFB, Nichersu I, Poruncia AP. Transformation of cultural values and their valorization by tourism in DDBR. Scientific Annals of the Danube Delta Institute for Research and Development. 2005; 11: 175-179.

[6] Şerban E. Delta Dunării - studiu turistic şi metodologic. Costeşti: Editura Ars Libri; 2008.

[7] Tanasă L. Studii şi cercetări de economie rurală. Bohatereț VM (coord.). Experiență în proiectele de cercetare pentru agricultură şi dezvoltare rurală, Tomul VIII. Iaşi: Editura “Terra Nostra”; 2009.

[8] Vaidianu MN. Fuzzy cognitive maps: diagnosis and scenarios for a better management process of visitors flows in Romanian Danube Delta Biosphere Reserve. Journal of Coastal Research, Special Issue. 2013; 65: 1063-1068. DOI: 10.2112/SI65-180.

[8] Impact of European Cultural Routes on SMEs' innovation and competitiveness. Available from: http://cultureroutes.net/sites/default/files/files/StudyCR en.pdf [Accessed 6th February 2020].

[9] Strategia integrata de dezvoltare durabila a Deltei Dunarii (2030). Availble from: https://www.fonduri-ue.ro/images/files/studiianalize/48101/6. Raport Strategie ro.pdf [Accessed 6th February 2020]. 